\title{
Identification of Bartonella henselae and B. quintana 16S rDNA sequences by branch-, genus- and species-specific amplification
}

\author{
C. DAUGA, I. MIRAS and P. A. D. GRIMONT \\ Unité des Entérobactéries, Institut National de la Santé et de la Recherche Médicale, Unité 389, Institut \\ Pasteur, F-75724 Paris Cedex 15, France
}

\begin{abstract}
Given the controversy surrounding the aetiology of cat scratch disease and the association of both Bartonella henselae and $B$. quintana with bacillary angiomatosis, a method for the direct detection in clinical samples of 16S rRNA from the Proteobacteria alpha subgroup was developed. The primary structure of amplified 16S rDNA was determined by cloning and sequencing. Three sequences were identified: one corresponded exactly to GenBank accession number M73229 (B. henselae); the second was related to, but distinct from, GenBank accession number $Z 11684$ (referred to as ' $B$. henselae variant'); and a third sequence was identical with GenBank accession number M73228 (B. quintana). No sequence corresponding to Afipia spp. was found. To speed identification and reduce the cost of analysis, a nested amplification method for $B$. henselae and $B$. quintana was devised. These techniques were applied to DNA extracted from 30 unfixed lymph node biopsies, two liver biopsies and 36 node pus samples from patients with suspected cat scratch disease, and from 17 skin biopsies from AIDS patients with suspected bacillary angiomatosis. $B$. henselae or $B$. henselae variant sequences were found in $42(62 \%)$ of 68 samples from suspected cat scratch disease. $B$. quintana was not associated with cat scratch disease, but a $B$. quintana sequence was found in seven (41\%) of 17 samples from suspected bacillary angiomatosis patients. $B$. henselae $16 \mathrm{~S}$ rDNA sequences were not found in bacillary angiomatosis specimens.
\end{abstract}

\section{Introduction}

Cat scratch disease (CSD) has been known for 45 years as an infectious disease transmitted to man by cats [1]. This relatively common cause of subacute regional lymphadenopathy is diagnosed currently on the basis of three of four criteria: contact with or scratch from a cat; negative conventional bacteriological results; positive skin test with heated purulent lymph node material from a patient with CSD; gramnegative bacilli visualised by Warthin Starry silver stain in lymph node tissues [2,3]. The precise identification of the aetiological agent has been the source of controversy. Various bacteria have been successively incriminated $[4,5]$, including Afipia felis and Rochalimaea henselae $[6,7]$, but at the present time $R$. henselae seems to be the only causal agent of CSD in the USA $[8,9]$.

Received 5 Dec. 1995; revised version accepted 22 Jan. 1996.

Corresponding author: Dr C. Dauga.
The AIDS epidemic has allowed the emergence of infections that were previously unknown or rare. Among these infections is bacillary epitheloid angiomatosis (BA). This debilitating systemic disease is characterised by vascular lesions that are generally cutaneous and less frequently hepatic, splenic, pulmonary or cerebral $[10,11]$. Molecular methods have implicated $R$. quintana in this disease, a bacterium described long ago as causing trench fever [9-12]. Both $R$. henselae and $R$. quintana have been isolated from bacillary angiomatosis in the USA [3-7, 13, 14].

Isolation of the causative bacterium from CSD and BA is tedious and often fails. Molecular methods now allow the detection of non-cultivable bacteria, based on 16S rRNA sequence comparisons [15]. Rapidly expanding international data bases now contain $c$. 3500 bacterial $16 \mathrm{~S}$ rRNA sequences. Use of these sequences has allowed the detection and identification of bacteria without culture [16].

The CSD and BA agents belong to the alpha subgroup 
of Proteobacteria [17]. In the phylogenetic tree, Rochalimaea spp. were found to be so close to Bartonella bacilliformis, that Rochalimaea spp. were transferred to the genus Bartonella [18]. Grahamella spp. were also included in the genus Bartonella [19]. The alpha subgroup of Proteobacteria also contains Afipia spp. [20].

In this work, no attempt was made to isolate the aetiological agents, but the rapidly expanding $16 \mathrm{~S}$ rRNA sequence databases were used to identify the agents associated with CSD and BA in France. Taking into account the potential diversity of agents causing CSD and BA, primers were designed to amplify selectively, from clinical samples, 16S rRNA genes (16S rDNA) from all members of the alpha subgroup of Proteobacteria. The primary structure of the amplified 16S rDNA was determined by cloning and sequencing. Comparison of the $16 \mathrm{~S}$ rDNA sequences obtained with the databases allowed the identification of any alpha-Proteobacteria (Bartonella spp., Afipia spp. or others). To speed identification, a nested amplification method was devised for $B$. henselae and B. quintana.

\section{Materials and methods}

\section{Bacterial strains}

The strains of bacteria used to evaluate the specificity of the PCR tests or as positive controls are listed in Table 1 [21]. B. elizabethae and B. vinsonii were grown on Chocolate Polyvitex Agar (Diagnostics Pasteur, Marnes-la-Coquette, France). B. henselae was grown on Columbia Agar supplemented with horse blood 10\% v/v and haemin (Diagnostics Pasteur) $250 \mathrm{mg} / \mathrm{L}$. Plates with Bartonella spp. were incubated for 5 days at $37^{\circ} \mathrm{C}$ in the presence of $\mathrm{CO}_{2} 5 \%$. A. felis was grown on charcoal-yeast extract agar for 2-3 days at $30^{\circ} \mathrm{C}$ without $\mathrm{CO}_{2}$ [6].

\section{Clinical samples}

Unfixed lymph node biopsy specimens $(\mathrm{n}=30)$ and lymph node aspirates $(n=36)$ were from patients diagnosed clinically as having CSD. Liver biopsies $(\mathrm{n}=2)$ were from hepatic peliosis. Skin biopsies $(\mathrm{n}=17)$ were from AIDS patients with suspected BA. All samples were incubated in a water bath at $65^{\circ} \mathrm{C}$ for $30 \mathrm{~min}$ to inactivate human immunodeficiency virus.

\section{DNA extraction}

DNA was extracted from cultures or clinical samples with a modification of a procedure described previously for rickettsiae [22]. Following incubation overnight at $55^{\circ} \mathrm{C}$ in lysis buffer $(0.5 \mathrm{M}$ Tris, $\mathrm{pH} 9$, $20 \mathrm{mM}$ EDTA, $10 \mathrm{mM} \mathrm{NaCl}$, SDS $1 \% \mathrm{w} / \mathrm{v}$ and proteinase K, Sigma, $1 \mathrm{mg} / \mathrm{ml}$ ), the DNA was purified by phenol-chloroform extraction and ethanol precipitation [23]. A negative control (all the reagents without DNA sample) was included in each experiment to ensure that none of the extraction buffers and reagents was contaminated with target DNA.

\section{S rDNA amplification}

Reaction mixtures were prepared in a laminar flow hood which was irradiated subsequently by UV light. A separate set of pipettes and aerosol-guarded tips were used exclusively for preparation of reaction mixtures to avoid contamination [24]. The areas used for PCR preparation were isolated from electrophoresis units.

PCR amplification was performed with a DNA Thermal Cycler Model 480 (Perkin Elmer). A blank control lacking template DNA was included in each experiment and yielded no amplification product, demonstrating that DNA contamination was not present. DNA extracted from A. felis was used as a

Table 1. Strains of bacteria used for evaluation or control purposes

\begin{tabular}{lll}
\hline Species & Strain & Status or origin \\
\hline Bartonella henselae & ATCC 49882, CIP 103737 & Type strain \\
Bartonella vinsonii & ATCC 152-VR, CIP 103738 & Type strain \\
Bartonella elizabethae & ATCC 49927, CIP 103761 & Type strain \\
Bartonella quintana & Clinical isolate & Human skin, France* \\
Bartonella bacilliformis & CIP 77.27 & Human blood, Peru \\
Afipia felis & ATCC 53690, CIP 103515 & Type strain \\
Agrobacterium tumefaciens & ATCC 23308, CIP 67.1 & Type strain \\
Brucella melitensis & CIP 65.2 & Type strain \\
Caulobacter bacteroides & CIP 101031 & Type strain \\
Rhodobacter sphaeroides & CIP 60.6 & Type strain \\
Sphingomonas paucimobilis & CIP 100752 & Type strain \\
Brevundimonas diminuta & CIP 63.27 & Type strain \\
Corynebacterium xerosis & ATCC 373 & Type strain \\
Escherichia coli & K12 wild type & \\
\hline
\end{tabular}

${ }^{*}$ Received from G. Arlet, Hopital Saint-Louis, Paris, France [21]. 
positive control. If no specific amplification product was detected and when a blur was seen on the agarose gel, the PCR was repeated with a 10- and 100-fold diluted sample to remove inhibitory compounds in the sample.

Two oligonucleotide primers, Alpha and r-Alpha (Table 2) [25], were used for 16S rDNA amplification before sequencing. These primers were selected on the basis of sequence conservation in the alpha subgroup of Proteobacteria after comparison of 87 Proteobacteria alpha subgroup $16 \mathrm{~S}$ rDNA sequences from GenBank [26]. Bio-Taq polymerase (Bioprobe, Montreuil-sous-bois, France) was used in amplification reactions consisting of $5 \mathrm{~min}$ at $94^{\circ} \mathrm{C} ; 35$ cycles of $94^{\circ} \mathrm{C}$ for $1 \mathrm{~min}, 65^{\circ} \mathrm{C}$ for $1 \mathrm{~min}$ and $72^{\circ} \mathrm{C}$ for $1 \mathrm{~min}$; and a final elongation step at $72^{\circ} \mathrm{C}$ for $5 \mathrm{~min}$.

Two other primers, A-proteo and r-Alpha-sh (Table 2), were also used in initial sequence experiments. Primer A-proteo was selected on the basis of sequence conservation in the Proteobacteria phylum. Primer $r-$ Alpha-sh is shorter than r-Alpha in order to have an annealing temperature compatible with that of primer A-proteo. Hi-Taq polymerase (Bioprobe) was used in amplification reactions identical to those above except that the primer hybridisation step was at $62^{\circ} \mathrm{C}$ for $1 \mathrm{~min}$.

Amplified products were detected by electrophoresis on an agarose $0.8 \% \mathrm{w} / \mathrm{v}$ gel in Tris-acetate-EDTA buffer ( $40 \mathrm{mM}$ Tris-acetate, $2 \mathrm{mM}$ EDTA, $\mathrm{pH}$ 8.0). A 1-kb DNA Ladder (Gibco-BRL) was used as a DNA size standard. Gels were stained with ethidium bromide and photographed by standard procedures.

\section{S rDNA cloning and sequencing}

To facilitate cloning, a 12-base dUMP-containing sequence (CUACUACUACUA) was added to the $5^{\prime}$ end of the PCR primers [27]. The resulting PCR product was cloned in pAMP1 plasmid with the CLONEAMP $^{\mathrm{TM}}$ System (Gibco-BRL). For each specimen, 12 clones were amplified in Escherichia coli strain MC1061. The presence of an insert was confirmed by digestion with Bam HI and Eco RI [23]. For each specimen, two clones were sequenced by 'cycle sequencing' (Amersham International) with universal primers complementary to plasmid or conserved regions of $16 \mathrm{~S}$ rDNA labelled with $\left[\gamma \mathrm{P}^{33}\right]$ ATP (Isotopchim, Ganagobie-Peyruis, France) [28, 29].

\section{Nested PCR and RFLP analysis}

Proteobacteria alpha subgroup 16S rDNA was amplified with $\mathrm{Hi}-\mathrm{Taq}$ polymerase and primers A-proteo and r-Alpha-sh (Table 2). The strains listed in Table 1 were used as positive or negative controls. Two samples known to contain different $B$. henselae $16 \mathrm{~S}$ rDNA sequences were also included as controls.

To detect Bartonella spp., PCR was performed with two oligonucleotide primers, Bart and r-BH (Table 2). Primer Bart (position 95) was selected after examination of 87 Proteobacteria alpha subgroup 16S rDNA sequences for sequence signature of the genus Bartonella. The target sequence of this primer was identical for $B$. henselae, $B$. quintana, $B$. vinsonii, $B$. doshiae and $B$. grahamii. The corresponding sequence of $B$. elizabethae differed from the other Bartonella sequences at six positions (mostly at the $5^{\prime}$ end of the oligonucleotide). Primer r-BH (position 1092) was deduced from the 16S rDNA signature sequence of $B$. henselae [14]. Nested PCR was performed with primer Bart, specific for genus Bartonella 16S rDNA, and reverse primer $\mathrm{r}-\mathrm{BH}$, specific for $B$. henselae $16 \mathrm{~S}$ rDNA, used at low stringency $\left(65^{\circ} \mathrm{C}\right)$. Depending on the amount of alpha 16S rDNA amplified product, the nested PCR was performed with $1 \mu 1$ of a 1 in 10 or 1 in 100 dilution of PCR product, and one cycle of predenaturation at $94^{\circ} \mathrm{C}$ for $5 \mathrm{~min}$, followed by 35 cycles comprising denaturation at $94^{\circ} \mathrm{C}$ for $1 \mathrm{~min}$,

Table 2. Oligonucleotide primers used for $16 \mathrm{~S}$ rDNA amplification

\begin{tabular}{|c|c|c|}
\hline Name and specificity & Sequence & Position* \\
\hline $\begin{array}{l}\text { Alpha } \\
\text { alpha subgroup }\end{array}$ & AGTGTAGAGGTRAAATTCGTAGATATT & $681-707$ \\
\hline $\begin{array}{l}\text { r-Alpha } \\
\text { alpha subgroup }\end{array}$ & CCATTGTAGCACGTGTGTAGCCCA & $1242-1219$ \\
\hline $\begin{array}{l}\text { A-proteo } \\
\text { Proteobacteria }\end{array}$ & AGAGTTTGATCMTGGCTCAGA & $8-28$ \\
\hline $\begin{array}{l}\text { r-Alpha-sh } \\
\text { alpha subgroup }\end{array}$ & GTAGCACGTGTGTAGCCCA & $1237-1219$ \\
\hline $\begin{array}{l}\text { Bart } \\
\quad \text { Bartonella spp. }\end{array}$ & CACTCTTTTAGAGTGAGCGGCAA & $95-107$ \\
\hline $\begin{array}{l}\mathrm{r}-\mathrm{BH} \\
\text { B. henselae }\end{array}$ & CCCCCTAGAGTGCCCAACCA $^{\dagger}$ & $1155-1131$ \\
\hline
\end{tabular}


annealing at $65^{\circ} \mathrm{C}$ for $1 \mathrm{~min}$, and extension at $72^{\circ} \mathrm{C}$ for $1 \mathrm{~min}$. The amplicons were then allowed to extend at $72^{\circ} \mathrm{C}$ for $5 \mathrm{~min}$. Amplified products were detected by electrophoresis as described above.

To identify $B$. quintana, $10-\mu 1$ portions of PCR mixes containing amplified Bartonella 16S rDNA fragment were digested with $H i n c l$ I. This enzyme cuts the $B$. quintana $16 \mathrm{~S}$ rDNA sequence at position 435 , as found on the restriction maps of $B$. quintana sequences (GenBank accession numbers M73228 and M11927). Restriction fragment length polymorphisms (RFLPs) were determined after electrophoresis of the digested DNA on agarose (Bioprobe) $1 \% \mathrm{w} / \mathrm{v}$ plus NuSieve agarose (FMC BioProducts, Rockland, ME, USA) $1 \% \mathrm{w} / \mathrm{v}$ gels. $B$. henselae was detected by performing the PCR with primers Bart and $\mathrm{r}-\mathrm{BH}$ at high stringency $\left(72^{\circ} \mathrm{C}\right)$. Nested PCR was performed under the conditions described above with an annealing temperature of $72^{\circ} \mathrm{C}$.

\section{Results}

$16 S$ rRNA gene sequence analysis

PCR amplification of Proteobacteria alpha subgroup 16S rDNA with primers Alpha and r-Alpha (Table 2) generated a 640-bp fragment for all Bartonella spp., A. felis and from 22 clinical samples. Included in the 22 clinical samples were cases in which PCR inhibition was suspected and dilution of the original samples yielded amplification products (c. 25\% of cases). No amplicon was obtained when E. coli or Corynebacterium xerosis DNA was used as the target.
No product was observed when the primers were used to amplify a negative control with no DNA template (data not shown).

The 640-bp fragments amplified from the 22 clinical specimens were cloned and sequenced. The 17 fragments amplified from 29 specimens derived from suspected cases of CSD were identical to $B$. henselae 16S rDNA. Of two suspected hepatic peliosis samples, one yielded 16S rDNA of $B$. henselae. Of the 13 samples from suspected cases of BA, four yielded $16 \mathrm{~S}$ rDNA of B. quintana.

A 1210-bp product, including the $5^{\prime}$ end of the $16 \mathrm{~S}$ rDNA, was produced with primers A-Proteo (specific for Proteobacteria) and r-Alpha-sh (specific for the alpha subgroup of Proteobacteria) when Bartonella spp., Brucella abortus, Agrobacterium tumefaciens, Caulobacter bacteroides, Rhodobacter bacteroides, Sphingomonas paucimobilis, Brevundimonas diminuta and the positive clinical samples listed above were used as templates for amplification (Fig. 1). The 1210bp PCR products contained two $B$. henselae $16 \mathrm{~S}$ rDNA sequences, one of which corresponded exactly to that of $B$. henselae strain ATCC 49882 (accession number: M73229) [7] and was found in five cases. The second sequence differed by three nucleotides (positions 1187-1189) from $B$. henselae accession number Z11684 [17] and was named ' $B$. henselae variant'. This sequence was found in 13 cases. The sequence variation was not the result of polymerasenucleotide incorporation errors because the 'new' sequences were found with two independently cloned PCR products. The $B$. quintana $16 \mathrm{~S}$ rDNA sequences

\section{$M 123456789$ M $1011121314151617 M$}

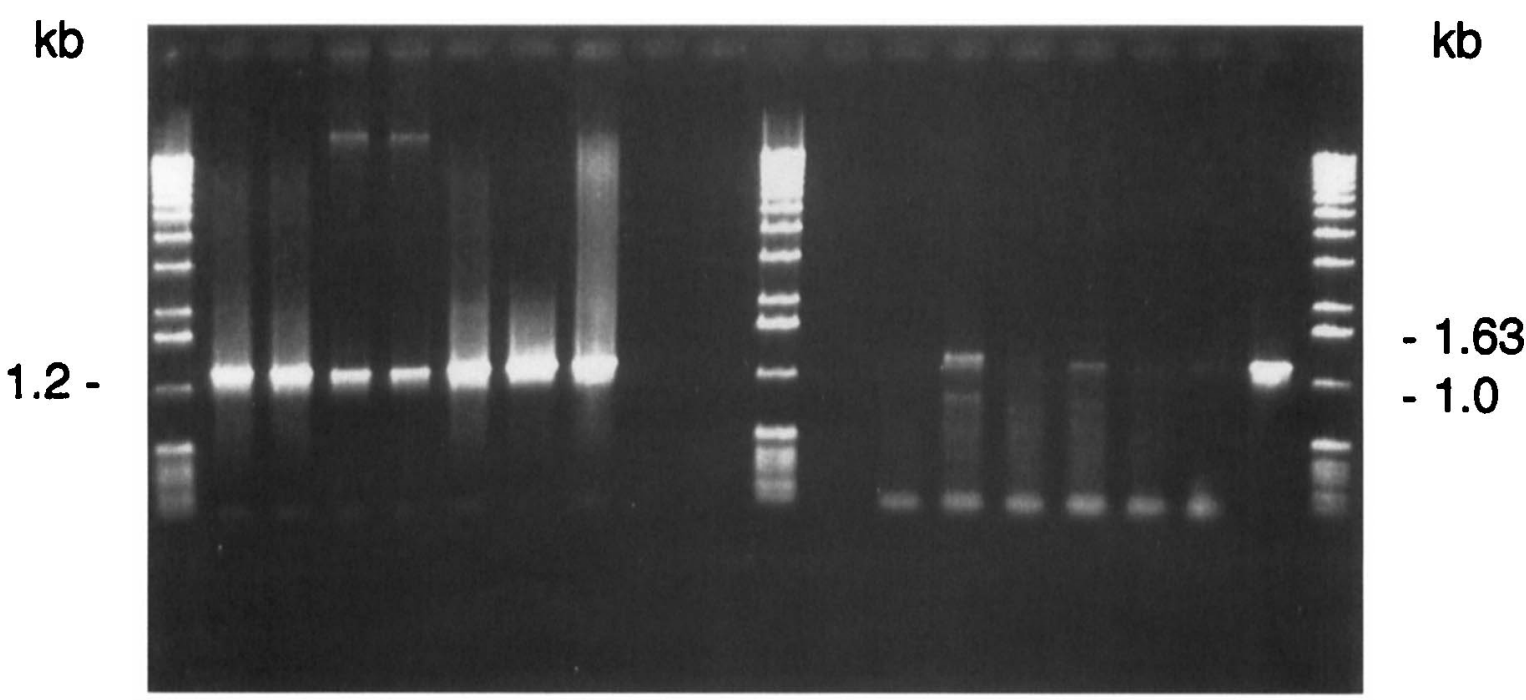

Fig. 1. Examples of specific amplification of $16 \mathrm{~S}$ rDNA fragments from the Proteobacteria alpha subgroup. Lanes: 1, $B$. henselae; 2 , specimen from case of CSD $(B$. henselae sequence); $\mathbf{3}, B$. quintana; $\mathbf{4}, B$. vinsonii; $\mathbf{5}$, B. elizabethae; 6 , A. felis; 7, Br. melitensis; 8, E. coli; 9, C. xerosis; 10-16, specimens from suspected cases of CSD; 17, specimen from suspected case of BA; M, DNA size markers. 
found corresponded exactly to the $16 \mathrm{~S}$ rDNA sequence of $B$. quintana strain ATCC VR-358 (accession number: M73228) [7]

\section{Nested PCR and RFLP analysis}

The nested amplification method was tested with 43 additional clinical samples and validated with Bartonella type strain DNA and three clinical specimens containing known $16 \mathrm{~S}$ rDNA sequences of $B$. henselae, $B$. henselae variant and $B$. quintana. A 1210-bp fragment was obtained after amplification with primers A-Proteo and r-Alpha-sh from 24 of 39 samples derived from suspected cases of CSD and from three of four samples derived from suspected cases of BA (Fig. 1).

Nested PCRs at low stringency $\left(65^{\circ} \mathrm{C}\right)$ with primers Bart and r-RH yielded a 990-bp amplicon that was specific for the genus Bartonella. Fig. 2A shows the PCR products obtained from representative strains of $B$. henselae (lane 1), B. vinsonii (lane 4), B. elizabethae (lane 5), B. quintana (lane 3), specimens from cases of CSD (lanes 2, b, e, f and g) and a case of BA (lane $\mathrm{h}$ ). No amplification product was observed for A. felis (lane 6), Brucella melitensis (lane 7), E. coli (lane 8), C. xerosis (lane 9), some clinical samples (lanes a, c and d) and negative controls containing no DNA template (data not shown).

Nested PCRs at high stringency $\left(72^{\circ} \mathrm{C}\right)$ with the same primers appeared to be specific for $B$. henselae. Fig. 2B shows the PCR products obtained for the type strain of $B$. henselae (lane 1) and specimens from cases of CSD (lanes 2, b, e, f and g). No amplification was observed for $B$. quintana (lane 3), $B$. vinsonii (lane 4), B. elizabethae (lane 5), A. felis (lane 6), Br. melitensis (lane 7), E. coli (lane 8), C. xerosis (lane 9), some samples from suspected cases of CSD (lanes a, c and d) and BA (lane h), and negative controls containing no DNA template (data not shown).

The HincII RFLPs could be used to identify $B$. quintana 16S rDNA in amplicons obtained at $65^{\circ} \mathrm{C}$. Two bands of 340 and $650 \mathrm{bp}$ were seen for the $B$. quintana DNA and the sample from a case of BA (Fig. 3; lanes 2 and 5, respectively).

Of 68 samples from suspected cases of CSD, 42 $(62 \%)$ yielded amplicons characteristic of $16 \mathrm{~S}$ rDNA from the Proteobacteria alpha subgroup. All of these amplicons corresponded to $B$. henselae.

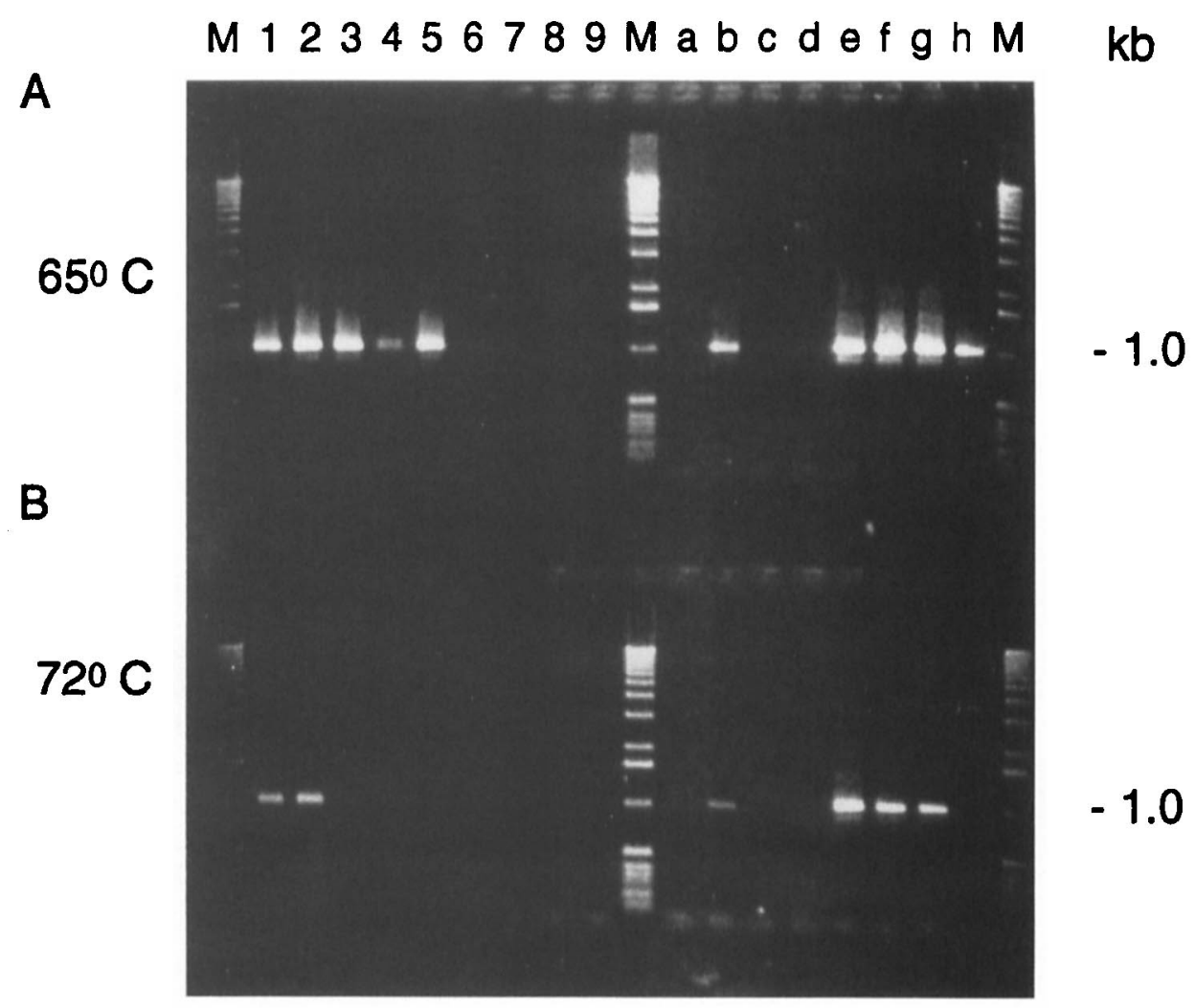

Fig. 2. A. Examples of specific amplification of $65^{\circ} \mathrm{C}$ of Bartonella $16 \mathrm{~S}$ rDNA. Lanes: 1, B. henselae; 2, specimen from case of CSD (B. henselae sequence); 3, B. quintana; 4, B. vinsonii; 5, B. elizabethae; 6, A. felis; 7, Br. melitensis; 8, E. coli; $\mathbf{9}, C$. xerosis; a-g, specimens from suspected cases of CSD; $\mathbf{h}$, specimen from suspected case of $\mathrm{BA}$; M, DNA size markers. B. Examples of specific amplification at $72^{\circ} \mathrm{C}$ of $B$. henselae $16 \mathrm{~S}$ rDNA. Lanes as for $\mathbf{A}$. 


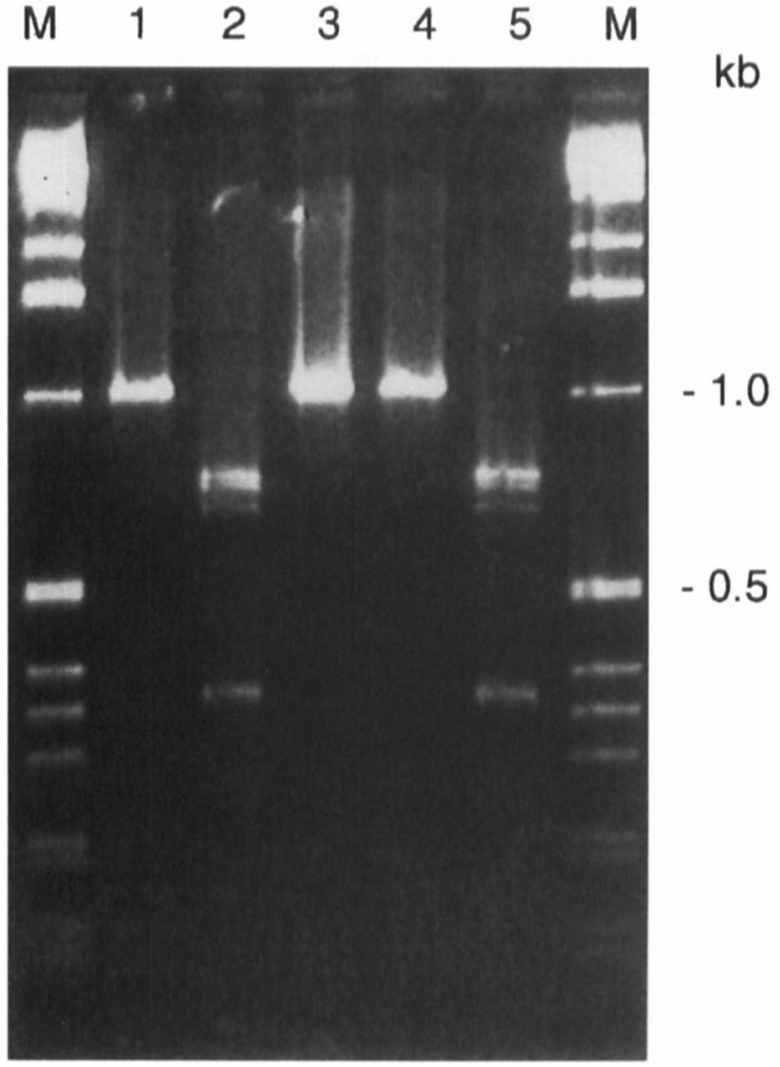

Fig. 3. Examples of restriction profiles obtained following Hincll digestion of Bartonella 16S rDNA amplicons. Lanes: 1, B. henselae; 2, B. quintana; 3, B. vinsonii; 4, $B$. elizabethae; $\mathbf{5}$, sample from suspected case of BA; $\mathbf{M}$, molecular size markers.

Of 17 samples of suspected cases of BA, seven (41\%) yielded amplicons characteristic of 16S rDNA from the Proteobacteria alpha subgroup. Sequencing or nested PCR indicated that this 16S rDNA corresponded to $B$ quintana (Figs. 2 and 3 ). No $B$. henselae sequence was associated with cutaneous $\mathrm{BA}$ infection in this study.

\section{Discussion}

In contrast to previous studies on the molecular diagnosis of Bartonella spp. [8,30], the present study was able to detect members of the Proteobacteria alpha subgroup directly in clinical samples. The $16 \mathrm{~S}$ rDNA sequencing method was able to identify bacteria accurately to the alpha subgroup of Proteobacteria, including known Bartonella and Afipia spp. as well as previously unrecognised bacteria. The method is easy to interpret when the sequence found corresponds exactly to a known sequence. However, a variant sequence was found which may correspond to $B$. henselae. This new variant sequence and two published sequences for $B$. henselae (accession numbers M73229 and Z11684) differ mostly in a hypervariable domain (position 150-170), with nucleotide differences corresponding to $0.2 \%$ of the complete $16 \mathrm{~S}$ rDNA sequence. Sequence variability within a species has not been defined properly. Two $16 \mathrm{~S}$ rDNA sequences have been described for $B$. quintana (accession numbers M11927 and M73228) [7,31], but only one type of $B$. quintana sequence was found in this study (M73228). Three different sequences have been reported for two strains of $B$. vinsonii (accession numbers Z31352, M73230, and LO1259) $[7,19,32]$. Three different sequences are also found for $B$. bacilliformis in GenBank (accession numbers X60042 [19], Z11683 [20] and M65249 [17]). Such diversity of sequences for one species may be caused by species heterogeneity [33], heterogeneity of $16 \mathrm{~S}$ rRNA copies within a strain [34], or sequencing errors. It is accepted that strains with $16 \mathrm{~S}$ rRNA homology values of $<97.5 \%$ are unlikely to belong to a single species [35], but identical or nearly identical sequences are not proof of identity at the species level [36]. The best solution to this problem would be to grow and isolate bacteria and then either perform quantitative DNA-DNA hybridisation or an identification test that correlates with DNA group assignment. However, when bacteria are non-cultivable, or cultivable only at very low efficiency, amplification and sequencing of rDNA may be the method of choice for use in a laboratory which is not specialised in the study of a particular bacterial group.

To reduce the costs and labour associated with DNA sequencing, a set of nested PCR tests was developed. Taking into account the potential diversity of agents causing CSD and BA, the PCR first amplifies a sequence specific for the Proteobacteria alpha subgroup. The second PCR indicates whether the amplified fragment corresponds to the genus Bartonella. Any amplified fragment not corresponding to Bartonella should be sequenced. The Bartonellaspecific PCR test can be used for species identification by repeating the PCR at a higher $\left(72^{\circ} \mathrm{C}\right)$ temperature (for $B$. henselae) or by HincII digestion of the PCR products (for B. quintana). No additional hybridisation steps are required for identification of these two species.

In total, $62 \%$ of samples from suspected cases of CSD gave positive results in the nested PCR specific for $B$. henselae. This is lower than the figure of $84 \%$ reported by Anderson et al. [8], but similar to the figure of $60 \%$ reported by Bergmans et al. [30]. The difference may be related to the type of cases selected. Anderson et al. [8] detected B. henselae DNA in $86 \%$ of patients with $B$. henselae antibody titres of $\geqslant 64$. The study by Bergmans et al. [30], and the present study, reported results from a group of patients who were only suspected as having CSD (lymphadenopathy, cat contact, absence of other obvious diagnosis). In this study, Bartonella antibody titres were known in only 19 cases, and only nine of 
these 19 patients had positive serology. Of these nine positive patients, eight $(88 \%)$ yielded a positive PCR test for Bartonella.

The major problem in clinical microbiology is to associate a micro-organism with a disease. Although A. felis was originally associated with CSD [6], the present study found that $B$. henselae sequences were associated with CSD when the Proteobacteria alpha subgroup amplification was positive. No Afipia sequences were found. In the USA, both $B$. henselae and $B$. quintana have been associated with BA $[7,13,14]$. It was surprising to find only the $B$. quintana sequence in skin biopsies when the Proteobacteria alpha subgroup amplification was positive. More specimens need to be studied to verify whether the aetiological agent of BA is limited to B. quintana in Europe. The nested PCR described in this paper is now used routinely in our Institute for this purpose.

Thanks are due to C. Bizet (CIP) for type strains, J. D. Poveda (Institut Pasteur) and colleagues in French hospitals who kindly provided clinical samples.

\section{References}

1. Debré R, Lamy M, Jammet ML, Costil L, Mozziconnaci P. La maladie des griffes du chat. Soc Med Hop Paris 1950; 26: 76-79.

2. Margileth AM, Wear DJ, English CK. Systemic cat scratch disease: report of 23 patients with prolonged or recurrent severe bacterial infection. $J$ Infect Dis $1987 ; 155$ : 390-402.

3. Regnery R, Tappero J. Unraveling mysteries associated with cat scratch disease, bacillary angiomatosis and related syndromes. Emerg Inf Dis 1995; 1: 16-21.

4. Emmons RW, Riggs JL, Schachter J. Continuing search for the etiology of cat scratch disease. J Clin Microbiol 1976; 4: 112114.

5. Gerber MA, Sedgwick AK, MaCalister TJ, Gustafson KB, Ballow M, Tilton RC. The aetiological agent of cat scratch disease. Lancet 1985; 1: 1236-1239.

6. Brenner DJ, Hollis DG, Moss CW et al. Proposal of Afipia gen. nov., with Afipia felis sp. nov. (formerly the cat scratch disease bacillus), Afipia clevelandensis sp. nov. (formerly the Cleveland Clinic Foundation strain), Afipia broomeae sp. nov. and three unnamed genospecies. J Clin Microbiol 1991; 29: 2450-2460.

7. Regnery RL, Anderson BE, Clarridge JE, Rodriguez-Barradas $\mathrm{MC}$, Jones DC, Carr JH. Characterization of a novel Rochalimea species, $R$. henselae sp. nov., isolated from blood of a febrile, human immunodeficiency virus-positive patient $J$ Clin Microbiol 1992; 30: 265-274.

8. Anderson B, Sims K, Regnery $\mathrm{R}$ et al. Detection of Rochalimaea henselae DNA in specimens from cat scratch disease patients by PCR. J Clin Microbiol 1994; 32: 942-948.

9. Tappero JW, Mohle-Boetani J, Koehler JE et al. The epidemiology of bacillary angiomatosis and bacillary peliosis. JAMA 1993; 269: 770-775.

10. Kemper CA, Lombard CM, Deresinski SC, Tompkins LS Visceral bacillary epitheloid angiomatosis: possible manifestations of disseminated cat scratch disease in the immunocompromised host: a report of two cases. Am J Med 1990; 89. 216-222.

11. LeBoit PE, Eegbert BM, Stoler MH et al. Epitheloid haemangioma-like vascular proliferation in AIDS: manifestations of cat scratch disease bacillus infection? Lancet 1988; 1 : 960-963.

12. Relman DA, Loutit JS, Schmidt TM, Falkow S, Tompkins LS The agent of bacillary angiomatosis. An approach to the identification of uncultured pathogens. $N$ Engl $J$ Med 1990; 323: $1573-1580$
13. Cockerell CJ, Tierno PM, Friedman-Kien AE, Kim KS Clinical, histologic, microbiologic, and biochemical characterization of the causative agent of bacillary (epitheloid) angiomatosis: a rickettsial illness with features of bartonellosis. J Invest Dermatol 1991; 97: 812-817.

14. Koehler JE, Quinn FD, Berger TG, LeBoit PE, Tappero JW Isolation of Rochalimaea species from cutaneous and osseous lesions of bacillary angiomatosis. $N$ Engl J Med 1992; 327: 1625-1631.

15. Woese CR. Bacterial evolution. Microbiol Rev 1987; 51: 221-271.

16. Chen $K$, Neimark $H$, Rumore $P$, Steinman CR. Broad range DNA probes for detecting and amplifying eubacterial nucleic acids. FEMS Microbiol Lett 1989; 57: 19-24.

17. Relman DA, Lepp PW, Sadler KN, Schmidt TM. Phylogenetic relationships among the agent of bacillary angiomatosis, Bartonella bacilliformis, and other alpha-proteobacteria. Mol Microbiol 1992; 6: 1801-1807.

18. Brenner DJ, O'Connor SP, Winkler HH, Steigerwalt AG. Proposals to unify the genera Bartonella and Rochalimaea, with descriptions of Bartonella quintana comb. nov., Bartonella vinsonii comb. nov., Bartonella henselae comb. nov., and Bartonella elizabethae comb. nov., and to remove the family Bartonellaceae from the order Rickettsiales. Int $J$ Syst Bacteriol 1993; 43: 777-786.

19. Birtles RJ, Harrisson TG, Saunders NA, Molyneux DH Proposals to unify the genera Grahamella and Bartonella, with descriptions of Bartonella talpae comb. nov. Bartonella peromysci comb. nov. and three new species, Bartonella grahamii sp. nov., Bartonella taylorii sp. nov., and Bartonella doshiae sp. nov. Int J Syst Bacteriol 1995; 45 $1-8$.

20. O'Connor SP, Dorsch $M$, Steigerwalt AG, Brenner DJ, Stackebrandt E. 16S rRNA sequences of Bartonella bacilliformis and cat scratch disease bacillus reveal phylogenetic relationships with the alpha-2 subgroup of the class Proteobacteria. J Clin Microbiol 1991; 29: 2144-2150.

21. Bachelez H, Oksenhendler E, Lebbe $\mathrm{C}$ et al. Bacillary angiomatosis in HIV-infected patients: Report of three cases with different evolutive modalities, and identification of Rochalimaea quintana as the aetiological agent. Br J Dermatol 1995; 133: 983-989.

22. Regnery RL, Spruill CL, Plikaytis BD. Genotypic identification of Rickettsiae and estimation of intraspecies sequence divergence for portions of two rickettsial genes. $J$ Bacteriol 1991; 173: 1576-1589.

23. Sambrook J, Fritsch EF, Maniatis $T$ (eds). Molecular cloning: a laboratory manual, 2nd edn. Cold Spring Harbor, NY, Cold Spring Harbor Laboratory Press. 1989.

24. Sarkar G, Sommer SS. Shedding light on PCR contamination. Nature 1990; 343: 27.

25. Brosius J, Palmer ML, Kennedy PJ, Noller HF. Complete nucleotide sequence of a $16 \mathrm{~S}$ ribosomal RNA gene from Escherichia coli. Proc Natl Acad Sci USA 1978; 75: 48014805 .

26. Bilofsky HS, Burks C. The GenBank ${ }^{\circledR}$ genetic sequence data bank. Nucleic Acids Res 1988; 16: 1861-1863.

27. Rashtchian A, Buchman GW, Schuster DM, Berninger MS Uracil DNA glycosylase-mediated cloning of polymerase chain reaction-amplified DNA: application to genomic and cDNA cloning. Anal Biochem 1992; 206: 91-97.

28. Blakesley RW. Cycle sequencing. In: Griffin H, Griffin A (eds) Methods in molecular biology: DNA sequencing protocols. Totowa, NJ, Humana Press Inc. 1993: 23: 209-217.

29. Embley TM, Smida J, Stackebandt E. Reverse transcriptase sequencing of $16 \mathrm{~S}$ ribosomal RNA from Faenia rectivirgula, Pseudonocardia thermophila and Saccharopolyspora hirsuta. Three wall type IV Actinomyces which lack mycolic acids. $J$ Gen Microbiol 1988; 134: 961-966.

30. Bergmans AMC, Groothedde J-W, Schellekens JFP, van Embden JDA, Ossewaarde JM, Schouls LM. Etiology of cat scratch disease: comparison of polymerase chain reaction detection of Bartonella (formerly Rochalimaea) and Afipia felis DNA with serology and skin tests. J Infect Dis 1995; 171: 916-923.

31. Weisburg WG, Woese CR, Dobson ME, Weiss E. A common origin of Rickettsiae and certain plant pathogens. Science 1985; 230: $556-558$

32. Daly JS, Worthington MG, Brenner DJ et al. Rochalimaea 
elizabethae sp. nov. isolated from a patient with endocarditis. $J$ Clin Microbiol 1993; 31: 872-881.

33. Koehler JE, Glaser CA, Tappero JW. Rochalimaea henselae infection. A new zoonosis with the domestic cat as reservoir. JAMA 1994; 271: 531-535.

34. Relman DA, Loutit JS. The agent of bacillary angiomatosis. $N$ Engl J Med 1991; 324: 1511-1513.

35. Stackebrandt E, Goebel BM. Taxonomic note: a place for
DNA-DNA reassociation and 16S rRNA sequence analysis in the present species definition in bacteriology. Int $J$ Syst Bacteriol 1994; 44: 846-849.

36. Ash C, Farrow JAE, Dorsch M, Stackebrandt E, Collins MD. Comparative analysis of Bacillus anthracis, Bacillus cereus, and related species on the basis of reverse transcriptase sequencing of 16S rRNA. Int J Syst Bacteriol 1991; 41: 343346. 